\title{
Life in the sea of plenty: Seasonal and regional comparison of physiological performance of Euphausia hanseni in the northern Benguela upwelling system
}

\author{
Thorsten Werner* ${ }^{*}$, Cornelia Buchholz, Friedrich Buchholz \\ Alfred Wegener Institute Helmholtz Centre for Polar and Marine Research, Am Handelshafen 12, 27570 Bremerhaven, Germany
}

\section{A R T I C L E I N F O}

Article history:

Received 28 August 2013

Received in revised form 8 June 2015

Accepted 28 June 2015

Available online $\mathrm{xxxx}$

\section{Keywords:}

Benguela Current

Euphausiids

Metabolism

Moult

Upwelling

Reproduction

Zooplankton

\begin{abstract}
A B S T R A C T
Variability in upwelling events may lead to periods of constrained food availability in the northern Benguela upwelling system (NBUS), thereby affecting the physiological state and metabolic activity of euphausiids. Most attention has so far been paid to seasonal effects but little is known about regional variability. Metabolic activity (expressed by respiration and excretion rates) and physiological state (expressed by reproductive effort and moult activity) in Euphausia hanseni were examined at different stations during austral summer (minimum upwelling) and austral winter (maximum upwelling). Overall, regional differences in physiological state, influencing metabolic activity, were greater than seasonal ones, indicating favourable conditions for growth and reproduction year-round. Higher respiration rates were found for females in more advanced stages of sexual development. Moult stage did not affect oxygen consumption rates, however. The physiological state of $E$. hanseni at the time of capture may serve as a meaningful indicator of the associated hydrographic conditions in the NBUS, to be further used in eco-system analysis on seasonal or long-term time scales. A latitudinal comparison of species highlights the extraordinary physiological plasticity of euphausiids.
\end{abstract}

(c) 2015 Elsevier B.V. All rights reserved.

\section{Introduction}

One of the four major Eastern Boundary upwelling systems, the northern Benguela upwelling system (NBUS), is located off the westcoast of Namibia. It is bordered in the north by the Angola-Benguela front $\left(\sim 17^{\circ} \mathrm{S}\right)$ and in the south by the strong upwelling cell at Lüderitz $\left(26^{\circ} \mathrm{S}\right)$. The NBUS is characterized by perennial upwelling, with a maximum during austral winter/spring and a minimum during austral summer/autumn. Influenced by several atmospheric and oceanographic processes, the NBUS is a complex and highly variable ecosystem (Shannon and Nelson, 1996). In addition, wind-driven coastal upwelling makes this area one of the most productive ecosystems in the world's oceans. Fluctuations in upwelling intensity correlate with variations in the magnitude and direction of winds. Timing and duration of upwelling events influence the physical and biological properties of coastal seas, including the population biology of krill (Dorman et al., 2005). In the NBUS the biomass and distribution of mesozooplankton are spatially and temporally highly variable and upwelling intensity shows a clear seasonal signal (Martin et al., 2014). Upwelling events favour phytoplankton growth through nutrient input and subsequent zooplankton blooms, thereby supporting omnivorous species like Euphausia hanseni, the dominant krill species in the NBUS.

\footnotetext{
* Corresponding author.

E-mail address: Thorsten.Werner@awi.de (T. Werner).
}

Consequently, E. hanseni may show physiological adaptations to these poly-pulsed, upwelling-mediated, plankton blooms. The adjustment of metabolic rates in krill to (seasonal) differences in abiotic (e.g., temperature, oxygen) and biotic (e.g., food availability) factors has been the target of several studies (e.g., Buchholz and Saborowski, 2000; Kim et al., 2010; Meyer et al., 2009, 2010; Saborowski et al., 2002). However, the effects of regional variability in the physical and biological environment on euphausiid physiology are largely unknown.

Physiological processes such as growth and reproduction are influenced by food availability. Accordingly, euphausiids adapt their reproductive cycles to local feeding conditions (Tarling and Cuzin-Roudy, 2003); both egg production and length of the reproductive period are controlled by temperature and trophic conditions (Cuzin-Roudy and Buchholz, 1999). Furthermore, the recruitment success of krill species depends both on adequate condition of the females prior to spawning and favourable trophic conditions during larval development (Tarling and Cuzin-Roudy, 2003). Growth in euphausiids is controlled mainly by temperature and food supply (Huntley and Boyd, 1984) and moulting accelerates both respiration and excretion rates (Ikeda and Mitchell, 1982). Furthermore, seasonal changes in food availability can alter the chemical composition of zooplankton, which in turn affects respiration and excretion rates (Conover and Corner, 1968). The Northern Krill (Meganyctiphanes norvegica) for instance, tunes metabolic activity to both thermal and trophic conditions: In the naturally oligotrophic Ligurian Sea growth and reproduction in $M$. norvegica are 
maximized during the short productive season (Buchholz and Saborowski, 2000). The spatial and temporal availability of food constrains the physiological state of zooplankton. To better understand the consequences of this variability for E. hanseni, seasonal comparisons of the physiology of krill species are necessary. Such investigations are aimed at assessing the potential effects of krill's physiological performance on lower and higher trophic levels (e.g., the commercially important horse mackerel Trachurus trachurus capensis) and the food web structure in the NBUS as a whole.

In the present paper, seasonal (austral winter/summer) and regional (mesoscale) differences in metabolic activity (respiration and excretion) and physiological states (moult activity and reproductive effort) of $E$. hanseni were examined and are discussed in relation to upwelling intensity/trophic conditions and to seasonal adaptations of other euphausiid species such as Antarctic Euphausia superba and boreal $M$. norvegica. Furthermore, the impact of growth, depicted by moult stages and the influence of reproductive activity, depicted by sexual developmental stages (SDSs), on the oxygen uptake in E. hanseni were determined.

\section{Materials and methods}

\subsection{Field sampling}

Juvenile and adult Euphausiids were collected on board the RRS Discovery in austral winter 2010 (10.09.-13.10.2010, cruise D356) and on board the RV Maria S. Merian in late austral summer 2011 (30.01.07.03.2011, cruise MSM17/3 (Werner et al., 2012)). Specimens were collected between Walvis Bay $\left(23^{\circ} \mathrm{S}\right)$ and Kunene $\left(17^{\circ} 25 \mathrm{~S}\right)$ in the northern Benguela upwelling system off Namibia. Krill were caught at different stations (8 stations during austral winter 2010; 5 Stations during austral summer 2011, Fig. 1) during nighttime with a $1-\mathrm{m}^{2}$ Multiple Opening and Closing Net with Environmental Sensing System (MOCNESS, Wiebe et al., 1985). Nighttime sampling ensured comparable catch depths, oriented at vertical migration in E. hanseni (see Werner and Buchholz, 2013) and prevented deep hauls causing stress on experimental individuals. A large mesh size $(2000 \mu \mathrm{m})$ and a large soft closed cod-end bucket were used to further decrease stress on the experimental animals.

Animals for metabolic measurements were randomly chosen and transferred to aerated plastic aquaria filled with filtered seawater. All adult $E$. hanseni used for experiments were actively swimming, appeared healthy without obvious damage. The remaining animals from each haul, or a representative subsample, were used to assess the physiological state of $E$. hanseni in the field.

\subsection{Hydrographic conditions}

For seasonal comparison of sea surface temperatures (SST) and Chl $a$ concentrations Moderate-Resolution Imaging Spectroradiometer (MODIS)-Aqua data, processed by the Ocean Biology Processing Group (OBPG) at Goddard Space Flight Center, were used. Ferrybox data (an automated monitoring system, especially for biological-chemical parameters, where water is pumped from subsurface layers into the measuring circuit of multiple sensors) provided by N. Lahajnar (University of Hamburg, Germany) were employed to determine small-scale differences in temperature $\left({ }^{\circ} \mathrm{C}\right)$ and salinity at the different sampling stations during austral winter.

\subsection{Metabolic measurements}

Respiration measurements were conducted using a closed respirometry system with Oxygen-Microsensors (PreSens, Germany) and a 4-channel micro-fibre optic oxygen transmitter (Oxy-4micro, PreSens, Germany) on board the research vessels. Specially designed small tube-shaped chambers (volume $20 \mathrm{~mL}$ ) were used

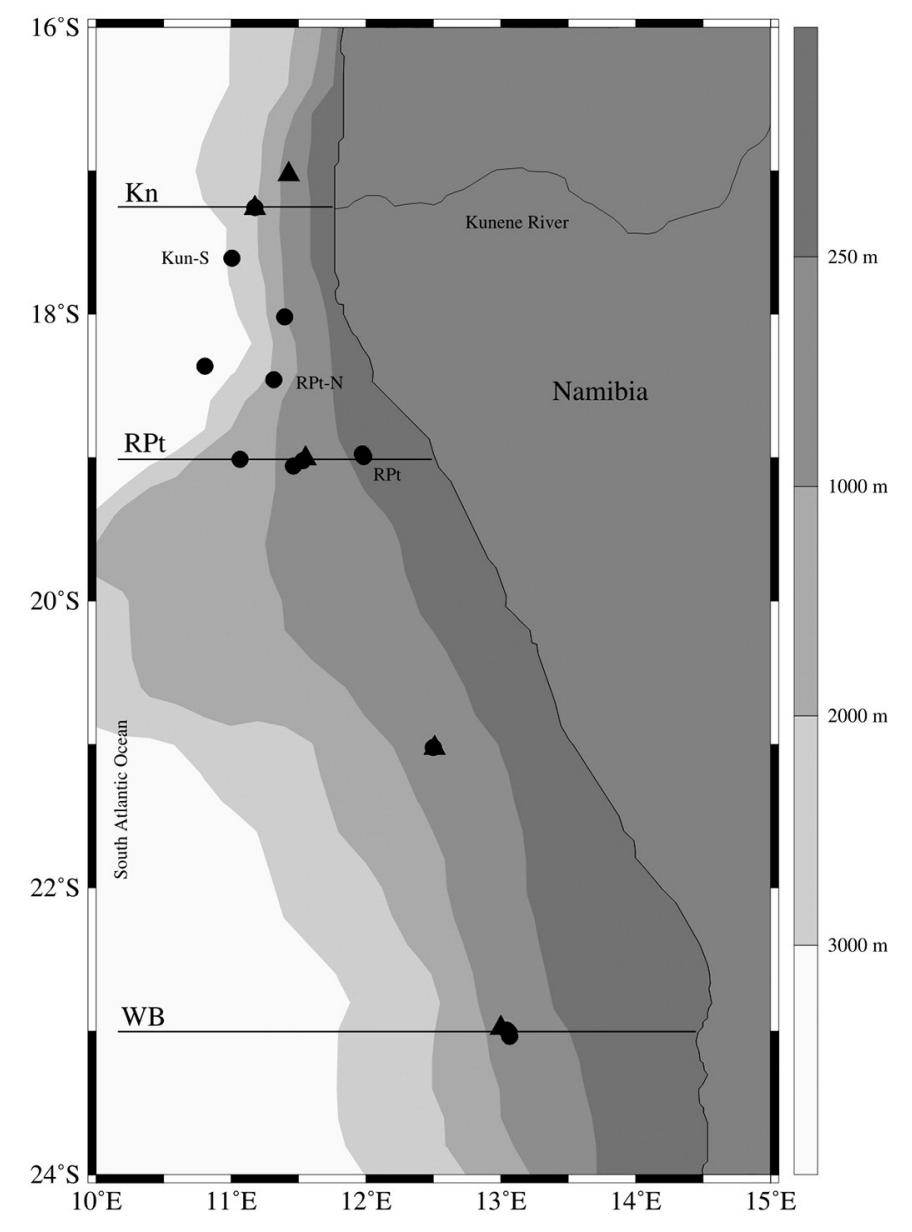

Fig. 1. Location of the northern Benguela upwelling system and stations sampled during austral winter 2010 (dots) and austral summer 2011 (triangles). Lines represent positions of transects: Walvis Bay (WB, $\left.23^{\circ} \mathrm{S}\right)$, Rocky Point (RPt, $\left.19^{\circ} \mathrm{S}\right)$ and Kunene (Kn, $\left.17.25^{\circ} \mathrm{S}\right)$. Stations used for regional comparison during austral winter 2010 are highlighted by acronyms (see text). This map was created using the ODV4 software (Schlitzer, 2015).

as respiration chambers optimized for krill (cf. Werner et al., 2012). As E. hanseni is a strong diel vertical migrator (Barange, 1990; Werner and Buchholz, 2013) respiration measurements were conducted in a temperature-controlled water bath at three different temperatures $\left(5,10\right.$ and $\left.15^{\circ} \mathrm{C}\right)$ reflecting the water temperatures around Walvis Bay $\left(23^{\circ} \mathrm{S}\right)$ between 50, 300 and deep water layers and around $700 \mathrm{~m}$ respectively. Regional comparisons of metabolic rates were conducted at $10{ }^{\circ} \mathrm{C}$ only. All experiments were performed within $24 \mathrm{~h}$ of capture in order to minimize confounding effects due to starvation (Huenerlage and Buchholz, 2013). E. hanseni adults were first acclimated for approximately $12 \mathrm{~h}$ at $8-10^{\circ} \mathrm{C}$ and then further acclimated to the experimental temperatures in the respiration chamber for 1 to $4 \mathrm{~h}$. The oxygen uptake was monitored in the dark over a period of 3 to $6 \mathrm{~h}$. Each temperature experiment was run in triplicate with an additional empty chamber to serve as the control. The respiration chambers were placed in a water bath, which was controlled by a lab cooler $\left( \pm 0.5^{\circ} \mathrm{C}\right.$; Julabo F25, Germany). Filtered seawater $\left(0.2 \mu \mathrm{m}\right.$ Acropak $^{\mathrm{TM}} 1000$ Capsule, Pall Filtersystems $\mathrm{GmbH}$, Germany) was used to minimize bacterial oxygen consumption. Since the metabolic rate of animals is known to vary both interspecifically and intraspecifically with body mass, respiration rates $\left(\mathrm{RR}_{\mathrm{O} 2}\right)$ were standardized to units of comparison of $\mu \mathrm{mol}$ $\mathrm{O}_{2} \mathrm{~h}^{-1} \mathrm{~g}_{\mathrm{ww}}{ }^{-1}$ ( $\mathrm{g}_{\mathrm{ww}}$ : grammes wet weight). After each experiment animals were sexed by identification of the thelycum (copulatory structure on underside of thorax of female euphausiids) or the petasma (modified endopodite of the first pair of pleopods of male 
euphausiids), measured for length (between the front of the eyes to the tip of the telson using a millimetre scale under a stereomicroscope) and their moult stage and sexual developmental stage (SDS) were determined (see 2.4). Thereafter animals were frozen and stored at $-20{ }^{\circ} \mathrm{C}$ for later determination of their wet mass using a microbalance (Sartorius LA $230 \mathrm{~S}, \mathrm{~d}=0.1 \mathrm{mg}$ ).

Measurement of respiration rates involved the analysis of $2 \mathrm{ml}$ water subsamples taken from the respiration chambers after each experiment which were immediately deep-frozen in liquid nitrogen and stored at $-80{ }^{\circ} \mathrm{C}$. At the home laboratory in Bremerhaven these subsamples were analyzed for ammonia $\left(\mathrm{NH}_{4}-\mathrm{N}\right)$, the major form of dissolved nitro-

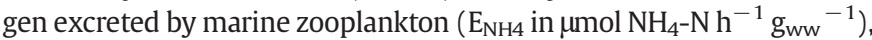
using the phenol-hypochlorid method following Solorzano (1969). The atomic O:N ratio was calculated by simple division between $\mathrm{RR}_{\mathrm{O} 2}$ and $\mathrm{E}_{\mathrm{NH} 4}$ in order to determine the dominantly-metabolized substrate (Mayzaud and Conover, 1988).

\subsection{Moult stages and sexual developmental stages}

The moult stage (MS) of E. hanseni specimen individuals was determined following Buchholz $(1982,1991)$, derived from Drach's method. At first, the hardness of the cuticule at the margin of the carapace was examined using fine forceps. Thereafter, one outer uropod was gently removed and placed on a micro slide with a drop of cooled sea water. Epidermal and cuticular structures were inspected for the described features given in Buchholz $(1982,1991)$ using a Zeiss microscope (100 $\times-400 \times$ magnification). The moult cycle is divided into MSs grouped into two phases: the postmoult period consists of MS A, B and C and the premoult period consists of MS $D_{0}, D_{1}, D_{2}$ and $D_{3}$, followed by ecdysis (E).

Sexual developmental stages (SDSs) of adult female E. hanseni were defined following a modified staging system by Cuzin-Roudy (1993), which scores each stage according to the development of the ovaries. Overall there are 5 different SDS stages, with SDSs 1 and 2 being characterized by ovaries still in development and differentiation. SDS 3 is defined by the occurrence of vitellogenesis and at SDSs 4 and higher, the ovaries have reached their full extension and eggs become ready to spawn (Table 1 ). At times animals were staged in increments of $1 / 3$ and/or $1 / 2$ (SDS of 3.5, 4.3, 4.5 and 4.7) to provide a more detailed picture. The SDSs were determined on live female krill, using a Leica MZ8 dissecting stereo microscope $(10 \times-40 \times$ magnification) to examine the extension and structure of the ovary. Sex ratio (female/ male) in a swarm was assessed from all the individuals caught at each station, or a representative subsample and males and females were checked for spermatophores.

\subsection{Statistical treatment of data}

Results are presented as means \pm standard deviations (SD) for regional comparison (equal sample size) and as means \pm standard errors (SE) for seasonal comparison (unequal sample size). Data were tested

Table 1

Maturity stages of adult krill females adapted to Euphausia hanseni.

\begin{tabular}{|c|c|}
\hline SDS & Description \\
\hline 1,0 & 1 or 2 spp* attached to thelycum, ovary grown to $1 / 3$ of full size \\
\hline 2,0 & 1 or 2 spp* attached to thelycum, ovary grown to $2 / 3$ of full size \\
\hline 3,0 & 1 or 2 spp* attached to thelycum, ovary grown to $3 / 4$ of full size \\
\hline 3,5 & Ovary full size \\
\hline 4,0 & Ovary full size, extension $1 / 3$ into first abdominal segment \\
\hline 4,3 & Mature oocytes begin to colour (orange) \\
\hline 4,5 & Mature oocytes lightly coloured \\
\hline 4,7 & Mature oocytes fully coloured, carapace swollen \\
\hline 5,0 & Batch spawned, shrunk ovary \\
\hline
\end{tabular}

\footnotetext{
* Sometimes spermatophores were not present, due to recent ecdysis.
}

for normality (Gaussian distribution) using the Kolmogorov-Smirnov ( small N) and/or the D'Agostino and Pearson omnibus normality test ( larger N). Either one-way ANOVAs or t-tests were performed according to the number of groups compared. Tukey's multiple comparison posttests were also performed following ANOVAs. Where required, data were transformed using log-transformation or were squared. If normalization was not possible, non-parametric tests like Kruskal-Wallis test with Dunn's post-test or a Mann-Whitney test were applied. F-tests were used to compare fits (e.g., the impact of temperature on the respiration rates between seasons). Tests for correlations between parameters following Gaussian distributions were performed with Pearson's correlation calculations. Spearman correlations were conducted if the data did not show a Gaussian distribution. All tests were performed using the GraphPad Prism software (Version 5.04). The significance level was set at $p<0.05$.

\section{Results}

\subsection{Hydrographic and trophic conditions}

Descriptions of the environmental dynamics in the NBUS are given by Shannon (1985), Mohrholz et al. (2001), Monteiro et al. (2008) and Hutchings et al. (2009). The hydrographic conditions during the sampling periods are described in Buchholz et al. (2010; report of cruise D356) and Lahajnar et al. (2011; report of cruise MSM17/3).

Seasonal differences in SST between austral winter 2010 and austral summer 2011 were apparent, as depicted by satellite images (MODISaqua from Goddard Earth Sciences Data and Information Services Center); however the trophic conditions ( $\mathrm{Chl} a$ in $\mathrm{mg} \mathrm{m}^{-3}$ ) during both seasons were relatively similar (Fig. 2). During austral summer 2011 the region between $17^{\circ} \mathrm{S}$ and $23^{\circ} \mathrm{S}$ was largely covered by warm upper water layers $\left(>20^{\circ} \mathrm{C}\right)$. In contrast, during austral winter 2010 , temperatures of the upper water layers ranged between $13{ }^{\circ} \mathrm{C}$ and $17^{\circ} \mathrm{C}$. During both seasons a narrow band of cooler water appeared along the coast with temperatures around $18-20^{\circ} \mathrm{C}$ in austral summer 2011 and $13-15^{\circ} \mathrm{C}$ in austral winter 2010 , suggesting recent coastal upwelling. The Chlorophyll $a$ content over the shelf was high (1$10+\mathrm{mg} \mathrm{m}^{-3}$ ) during both seasons. Trophic conditions offshore, construed from Chl $a$ concentrations, were more favourable during austral winter 2010 compared to the conditions during austral summer 2011 (Fig. 2). Monthly Chlorophyll $a$ values, derived from satellite images (Modis-Aqua, GES DISC), over the course of one year (September 2010-September 2011) and integrated over the whole sampling area $\left(11-14^{\circ} \mathrm{E}, 17-23^{\circ} \mathrm{S}\right)$ ranged between $1.5-3.5 \mathrm{mg} \mathrm{m}^{-3}$, indicative of a constant high phytoplankton biomass in the NBUS irrespective of the prevailing upwelling situation. Highest $\mathrm{Chl} a$ values $>3 \mathrm{mg} \mathrm{m}^{-3}$ were observed from May to July 2011, whereas during the rest of the year Chl $a$ values fluctuated between $1.5-2.3 \mathrm{mg} \mathrm{m}^{-3}$.

An overview of the hydrographic conditions (temperature $\left({ }^{\circ} \mathrm{C}\right)$ and salinity), derived from Ferrybox-measurements at the different sampling stations during austral winter 2010 is given in Table 2. Sampling stations, RPt and Kun-S, were characterized by cold upper water layers bearing low salinities, whereas RPt-N was influenced by slightly warmer and more saline surface water.

\subsection{Seasonal comparison}

\subsubsection{Size frequency and sex ratios}

Animals used for analyses of moult and sexual developmental stages were also used for determination of length frequencies (Fig. 3) and sex ratios. In general, mean length ( $\mathrm{mm}$ ) was slightly larger during austral summer $2011(22.6 \pm 0.14(\mathrm{SE}) ; \mathrm{N}=188)$ and sex ratios $(\mathrm{f} / \mathrm{m})$ was lower (1:0.8) compared to austral winter 2010 with $22.1 \pm 0.13(\mathrm{SE})$ and $1: 0.6(\mathrm{~N}=397)$ respectively. Medians of size did not differ significantly between austral summer 

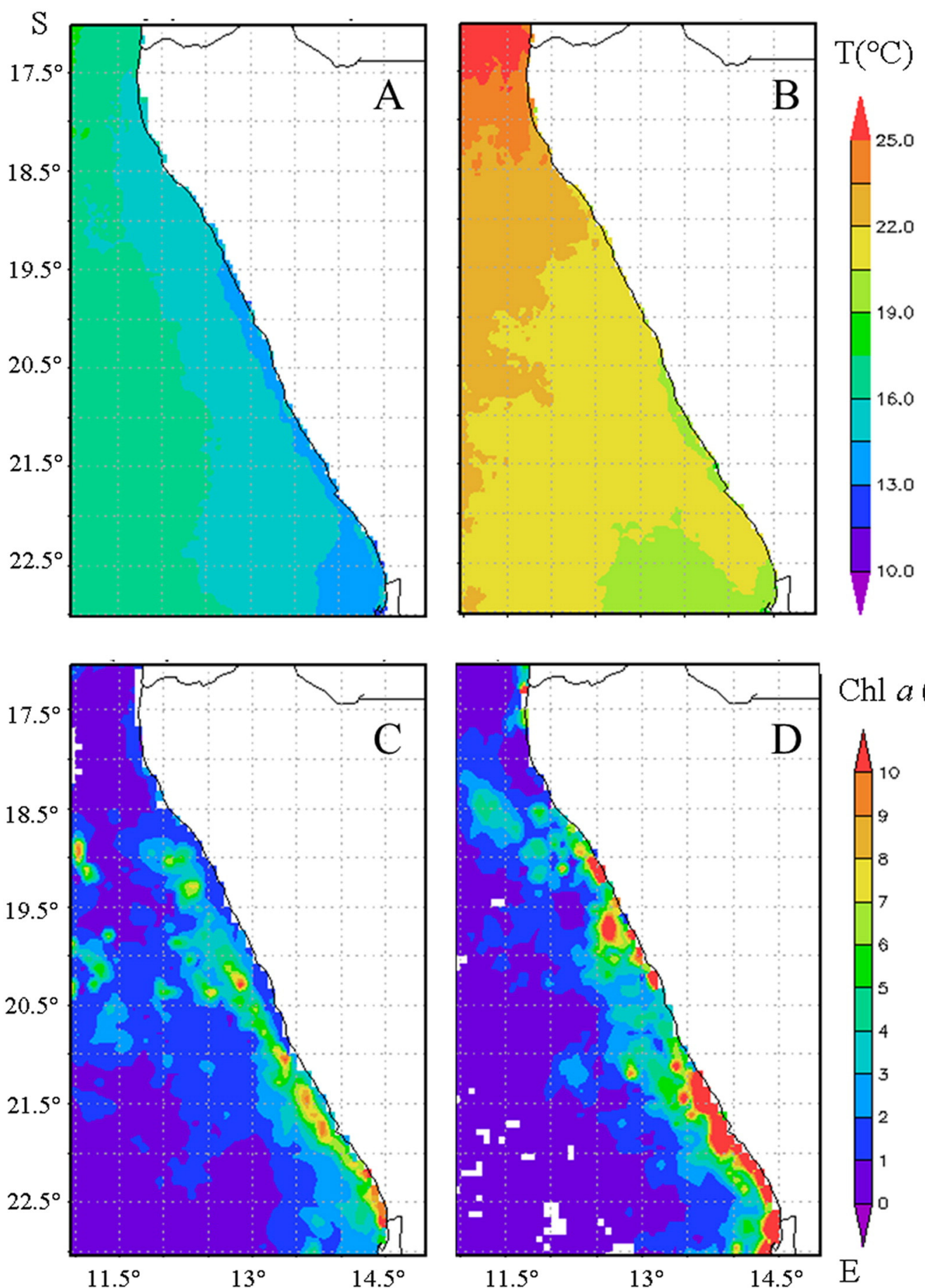

\section{Chl $a\left(\mathrm{mg} \mathrm{m}^{-3}\right)$}

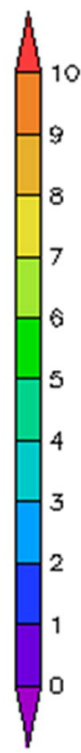

$11.5^{\circ}$

$13^{\circ}$

$14.5^{\circ}$

$\mathrm{E}$

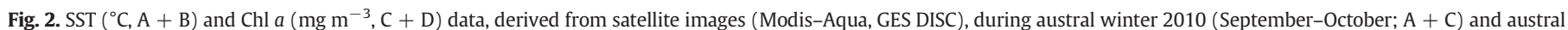
summer 2011 (February-March; B + D).

and winter (Mann-Whitney U-test, $p>0.05$ ) and females were significantly larger than males (Mann-Whitney U-test, $p<0.05$ ) in both seasons.

Table 2

Temperature $\left({ }^{\circ} \mathrm{C}\right)$ and salinity derived from Ferrybox-measurements at the three sampling stations used for regional comparison during austral winter 2010. Given are means $\pm \mathrm{SD}$.

\begin{tabular}{lll}
\hline Winter 2010 & Temperature $\left({ }^{\circ} \mathrm{C}\right)$ & Salinity \\
\hline RPt & $15.1 \pm 0.3$ & $35.3 \pm 0.04$ \\
RPt-N & $17.6 \pm 0.8$ & $35.8 \pm 0.21$ \\
Kun-S & $16.2 \pm 0.2$ & $35.4 \pm 0.03$ \\
\hline
\end{tabular}

\subsubsection{Respiration, excretion and $0: N$ ratio}

Temperature $\left(5-15{ }^{\circ} \mathrm{C}\right)$ had the same impact on oxygen uptake in E. hanseni individuals during austral winter 2010 and late austral summer 2011. No significant differences were detected between the slopes of the linear regressions describing the temperature/metabolism relationship (F-test, $\mathrm{F}=0.027, p=$ 0.8846 ; Fig, 5). The relationships between temperature $\left(5-15^{\circ} \mathrm{C}\right)$ and respiration rates shown in Fig. 4 can be expressed by linear regressions:

$\mathrm{RR}_{\mathrm{O} 2}=0.6 * \mathrm{~T}-4.733 \quad$-austral summer 2011 


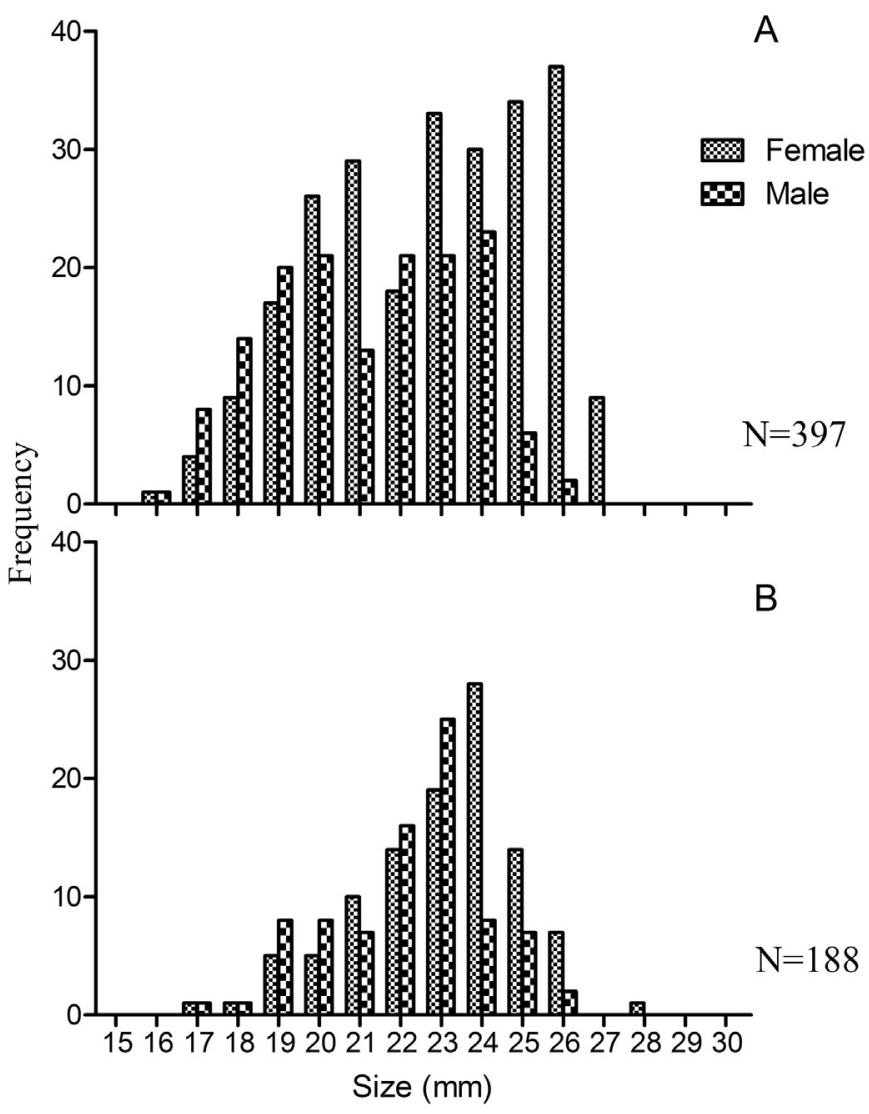

Fig. 3. Length-frequency distribution of $E$. hanseni males and females during (A) austral winter 2010 and (B) late austral summer 2011.

$\left(\mathrm{N}=40 ; \mathrm{R}^{2}=0.85\right.$; data taken from Werner et al., 2012)

$\mathrm{RR}_{02}=0.65 * \mathrm{~T}-4.933 \quad$-austral winter 2010

$$
\left(\mathrm{N}=56, \mathrm{R}^{2}=0.94\right) \text {. }
$$

Neither were significant differences found between $\mathrm{RR}_{\mathrm{O} 2}$ at $5{ }^{\circ} \mathrm{C}$ (unpaired t-test, $\mathrm{df}=17, p>0.05), 10{ }^{\circ} \mathrm{C}(\mathrm{df}=62, p>0.05)$ and $15{ }^{\circ} \mathrm{C}(\mathrm{df}=11, p>0.05)$ between austral summer and winter, nor

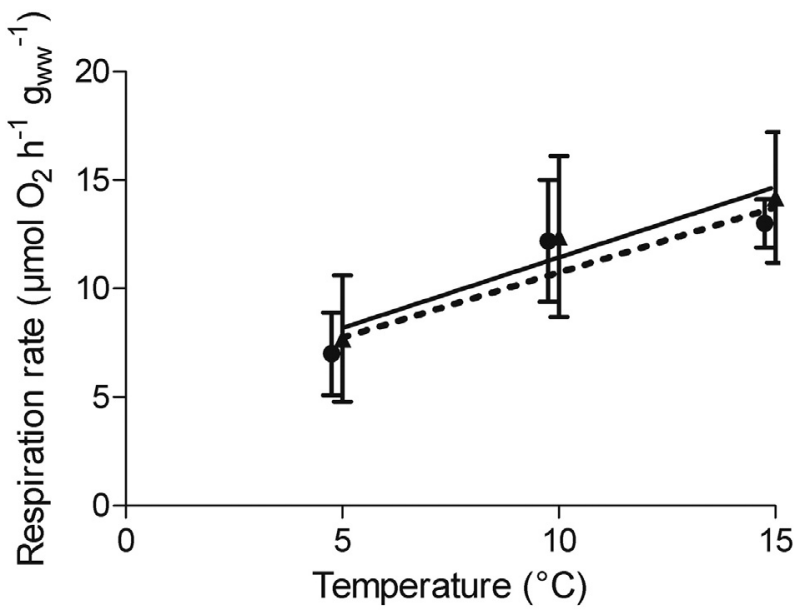

-.. winter 2010

summer 2011

Fig. 4. Linear-regressions of mean oxygen uptake ( $\mu \mathrm{mol} \mathrm{O}_{2} \mathrm{~h}^{-1} \mathrm{~g}_{\mathrm{ww}}^{-1}$ ) at different experimental temperatures $\left(5-15^{\circ} \mathrm{C}\right.$ ) during austral winter 2010 (circles and dotted line, $\mathrm{R}^{2}=0.85$ ) and austral summer 2011 (triangles and straight line, $\mathrm{R}^{2}=0.94$; data from Werner et al., 2012). Error bars denote SD. showed ammonia excretion rates at $10{ }^{\circ} \mathrm{C}$ significant differences between austral winter and summer (unpaired t-test, $\mathrm{df}=56, p>0.05$ ). Likewise there were no significant differences detected in the $0: \mathrm{N}$ ratios between seasons (Mann Whitney test, $p>0.05$ ).

\subsubsection{Moult stages and sexual developmental stages}

Moult activities in the E. hanseni populations were quantified as the proportion of individuals within an active moult stage $\left(A, B, D_{3}\right.$ and the ecdysis stage) at the time of sampling. In an average krill population, this number is approximately 15\% (Buchholz and Buchholz, 2010). The populations sampled during austral winter 2010 showed $16 \%$ of the animals in an active moult stage; $44 \%$ were in postmoult (A, B and C) and $54 \%$ in premoult stages $\left(D_{0}, D_{1}, D_{2}, D_{3}\right), 2 \%$ were present in ecdysis. However, $50 \%$ of the animals were in "resting" stages (Buchholz and Buchholz, 2010) C or $\mathrm{D}_{2}$. In contrast, during austral summer $201134 \%$ of the animals were in an active moult stage, with $55 \%$ in postmoult and $45 \%$ in premoult stages. None were found in ecdysis and only $38 \%$ were found in $\mathrm{C}$ or $\mathrm{D}_{2}$ (Table 3 ).

Most of the females during austral winter and summer were vitellogenic, with $71 \%$ in austral winter and $60 \%$ in austral summer. In austral winter $39 \%$ of $E$. hanseni individuals were in SDS 4 or 5, thus "ready to spawn" (Cuzin-Roudy and Buchholz, 1999), whereas during austral summer only $26 \%$ of the animals were in SDS 4 or 5 . In austral winter $201030 \%$ of the animals were still at the onset of the ovarian development, with 15\% being in SDS 1 (Oogenesis) and 15\% being in SDS 2 (Previtellogenesis). Slightly different percentages were observed in austral summer, with 9\% of females showing Oogenesis and 31\% being in Previtellogenesis. In both seasons most of the animals were in SDS 3, with 32\% in austral winter and 34\% in austral summer respectively (Table 4).

In austral winter season $201074 \%$ of females showed spermatophores attached to their thelycum, $26 \%$ were found without any spermatophores $(\mathrm{N}=248)$. In males $90 \%(\mathrm{~N}=150)$ were carrying spermatophores in their ejaculatory ducts. Out of the 103 females analyzed during austral summer 2011 79\% were bearing spermatophores, whereas $100 \%$ of males $(N=83)$ were having fully developed spermatophores in their ejaculatory duct. An abstract of the comparison in the physiological performance of $E$. hanseni between minimum and maximum upwelling season is shown in Fig. 5.

\subsection{Regional comparison}

\subsubsection{Size frequencies and sex ratios}

E. hanseni at the three stations (RPt, RPt-N and Kun-S, see Fig. 1) used for regional comparison during austral winter 2010 differed significantly in total length, weight and sex ratios. The mean krill length at RPt (24.7 $\mathrm{mm} \pm 1.5(\mathrm{SD})$, range $20-27 \mathrm{~mm}, \mathrm{~N}=49$ ) was significantly larger than that at RPt-N (20.0 $\mathrm{mm} \pm 2.1(\mathrm{SD})$, range $14-25 \mathrm{~mm}, \mathrm{~N}=69)$ and Kun-S (21.1 mm $\pm 1.6(\mathrm{SD})$, range $17-25 \mathrm{~mm}, \mathrm{~N}=44$ ) (Kruskal-Wallis test with Dunn's post-test, $\mathrm{H}=86.66, p<0.01$ ).

Accordingly, the mean weight of the krill was lowest at RPt-N $(53.9 \pm 9.1 \mathrm{mg}(\mathrm{SD}), \mathrm{N}=10)$ followed by Kun-S $(65.5 \mathrm{mg} \pm 10.2$ $(\mathrm{SD}), \mathrm{N}=10)$. Highest mean weights were recorded at $\mathrm{RPt}$ (111.7 $\mathrm{mg} \pm 14.7(\mathrm{SD}), \mathrm{N}=10$ ). The sex ratio (female/male) was highest at RPt (1:0.2; $\mathrm{N}=49)$ whereas the sex ratios at Kun-S (1:0.7; $\mathrm{N}=44)$ and $\mathrm{RPt}-\mathrm{N}(1: 0.8 ; \mathrm{N}=69)$ were considerably lower. Although

Table 3

Distribution (\%) of moult phases of E. hanseni during austral winter 2010 and austral summer 2011.

\begin{tabular}{|c|c|c|c|c|c|}
\hline & $\begin{array}{l}\text { Postmoult } \\
(\%)\end{array}$ & $\begin{array}{l}\text { Premoult } \\
(\%)\end{array}$ & $\begin{array}{l}\text { Active stages } \\
(\%)\end{array}$ & $\begin{array}{l}\text { Resting stages } \\
(\%)\end{array}$ & $\mathrm{N}$ \\
\hline & $(\mathrm{A}, \mathrm{B}, \mathrm{C})$ & $\left(D_{0}, D_{1}, D_{2}, D_{3}\right)$ & $\left(\mathrm{A}, \mathrm{B}, \mathrm{D}_{3}, \mathrm{E}\right)$ & $\left(\mathrm{C}, \mathrm{D}_{2}\right)$ & \\
\hline Winter 2010 & 44 & 54 & 16 & 50 & 404 \\
\hline Summer 2011 & 55 & 45 & 34 & 38 & 189 \\
\hline
\end{tabular}


Distribution (\%) of sexual maturity stages (\%) of E. hanseni during austral winter 2010 and austral summer 2011.

\begin{tabular}{|c|c|c|c|c|c|}
\hline & $\begin{array}{l}\text { SDS 1-2 } \\
(\%)\end{array}$ & $\begin{array}{l}\text { SDS 3-5 } \\
(\%)\end{array}$ & $\begin{array}{l}\text { SDS } 3 \\
(\%)\end{array}$ & $\begin{array}{l}\text { SDS 4-5 } \\
(\%)\end{array}$ & $\mathrm{N}$ \\
\hline & (Onset of ovarian development) & (Vitellogenic) & (Egg maturation) & (Ready to spawn) & \\
\hline Winter 2010 & 30 & 71 & 32 & 39 & 233 \\
\hline Summer 2011 & 40 & 60 & 34 & 26 & 103 \\
\hline
\end{tabular}

specimens taken for determination of metabolic parameters (respiration and excretion rates) were randomly chosen from the pool of specimens at each station, size frequencies and sex ratios reflected the in situ ratios at the sampling stations (unpaired t-tests with Welch's correction, $p>0.05$ ), except at RPt where the sex ratio of the experimental animals was more male-biased than the field sample.

\subsubsection{Respiration, excretion and O: $N$ ratio}

No significant differences could be detected between females and males in terms of their respiration rates (unpaired t-test, $\mathrm{t}=0.6745$, $\mathrm{df}=40, p>0.05)$, excretion rates $(\mathrm{df}=36, p>0.05)$ and $0: \mathrm{N}$ ratios ( $\mathrm{df}=36, p>0.05$ ). Thus, data from both sexes were pooled for subsequent analyses. Respiration rates of E. hanseni individuals at RPt-N
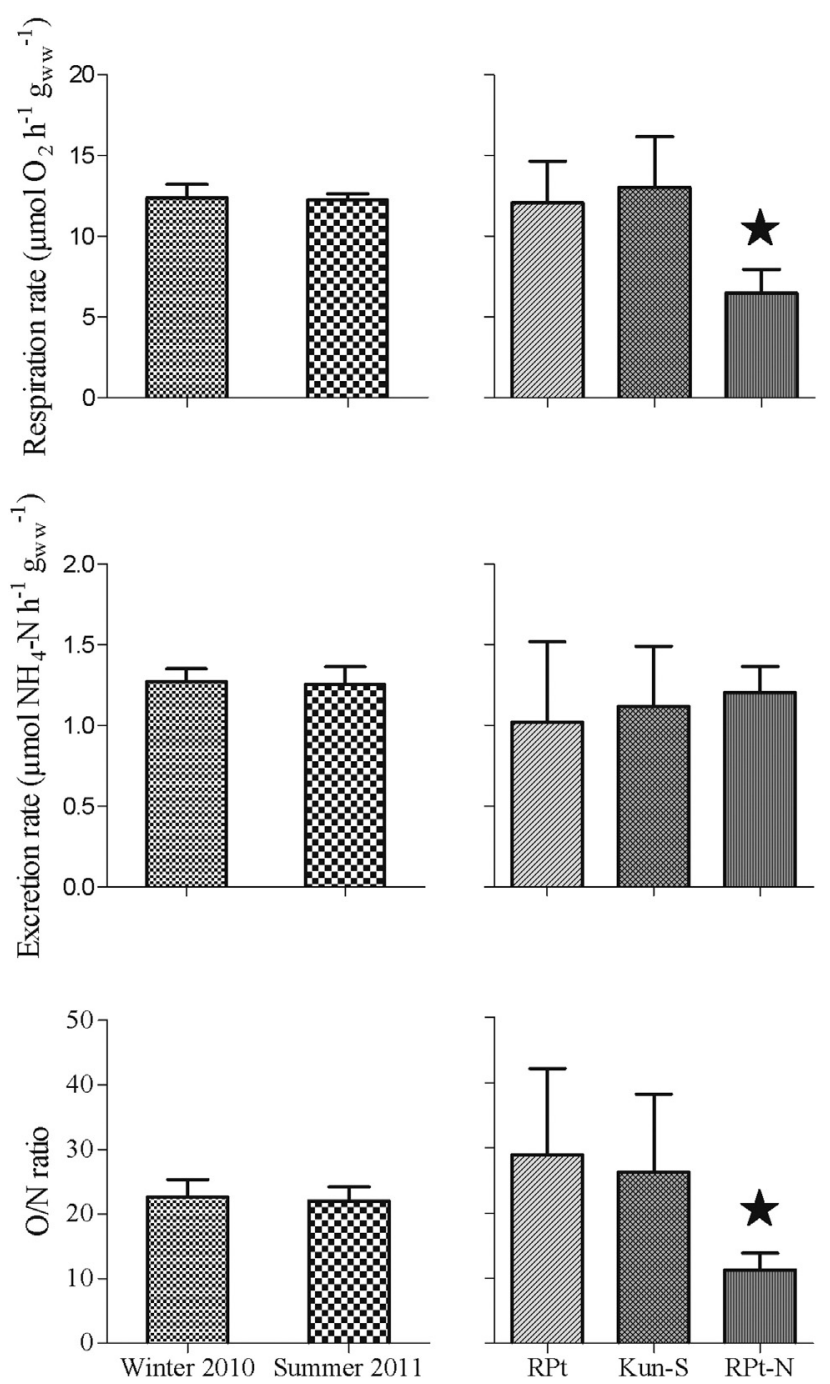

Fig. 5. Comparison of the physiological state (Resp, Excr, O:N) of E. hanseni during austral winter 2010 and austral summer 2011 (left) and between different sampling stations (RPt, RPt-N, Kun-S) during austral winter 2010 (right). Asterisk indicates significant differences between seasons or stations (ANOVA with Tukey's Multiple Comparison Test). were significantly lower compared to the other stations (ANOVA with Tukey's post-test, $\mathrm{F}_{2,27}=19.96, p<0.01$ ). However, no significant differences were found between mean excretion rates (ANOVA with Tukey's post-test, $\mathrm{F}_{2,23}=3.633, p=0.9$ ). Calculated $\mathrm{O}: \mathrm{N}$ ratios ranged from 9-16 at RPt-N, from 14-53 at RPt and from 10-36 at Kun-S. The $\mathrm{O}: \mathrm{N}$ ratio at station RPt-N was significantly different from that at RPt and Kun-S (ANOVA with Tukey's post-test, $\mathrm{F}_{2,23}=8.774, p<0.01$ ).

\subsubsection{Moult stages and sexual developmental stages (SDS)}

At RPt-N, $59 \%$ of the animals sampled $(\mathrm{N}=69)$ were in postmoult stages and $41 \%$ in premoult stages. $14 \%$ of the animals investigated were in an active moult stage, with $6 \%$ present in ecdysis. $55 \%$ of the population was in resting stage $\mathrm{C}$ or $\mathrm{D}_{2}$. At RPt $(\mathrm{N}=49)$ only $27 \%$ of the population was in postmoult stages and $73 \%$ in premoult stages, with $51 \%$ of the animals being in stage $C$ or $D_{2}$. No animals were found in an active moult stage. Kun- $\mathrm{S}(\mathrm{N}=44)$ showed $45 \%$ of the population in postmoult and $52 \%$ in premoult stages. $27 \%$ of the population was in active moult stages, with $2 \%$ shedding their shell. $43 \%$ of the animals caught at this station were in resting stages (Table 5).

The sexual developmental stage of the females at RPt-N was significantly lower compared to the two other stations (ANOVA with Tukey's post-test, $F_{2,13}=27.21, \mathrm{P}<0.01$ ). Here, $79 \%$ of females were at the onset of ovarian development and no animals were found "ready to spawn". In contrast, at station RPt $60 \%$ and Kun-S $84 \%$ of the females were "ready to spawn" and almost no animals were found to be at the onset of their ovarian development (Table 6). An overview of the physiological performance of $E$. hanseni at different sampling stations during upwelling season is shown in Fig. 5.

\subsection{Influence of MS and SDS on oxygen uptake}

Animals collected at additional stations during austral winter 2010 were used to study the influence of MS and SDS on the respiration rate of $E$. hanseni. Irrespective of regional differences, most of the animals investigated were in MS C (33\%). However, moult stages did not significantly affect the metabolic activity of $E$. hanseni (ANOVA, $\mathrm{F}_{5,53}=1.32, p>0.05$; Fig. 6 ), but a trend may be noted for a higher oxygen demand during active moult stages $\left(A, B, D_{3}\right.$ and $\left.E\right)$ compared to non-active $\left(D_{0}, D_{1}\right)$ and resting stages $\left(C, D_{2} ;\right.$ ANOVA; $F_{2,53}=2.86$, $p=0.056)$.

Respiration rates regressed against SDS (Fig. 7) showed a non-linear relationship $\left(r^{2}=0.42\right)$ expressed by:

$$
\text { one-phase association : } \quad \begin{aligned}
\mathrm{RR}_{\mathrm{O} 2}= & -6.761+18.981 \\
& *(1-\exp (-1.114 * \mathrm{SDS})) .
\end{aligned}
$$

The oxygen uptake was lowest at SDS 1, increased until SDS 3 and then levelled off. The high variability associated with oxygen uptake at SDS3 should be noted (Fig. 7). Significant differences were found between SDS 1 and SDS $3+$ (ANOVA with Tukey's post-test, $\mathrm{F}_{8,34}=$ $4.968, p<0.01)$. There was a significant and positive correlation between SDS and oxygen uptake in E. hanseni individuals (Spearman correlation, $\mathrm{r}_{\mathrm{s}}=0.74, \mathrm{~N}=46, \mathrm{p}=0.023$ ). 


\section{Discussion}

Adjustment of metabolic rates, in terms of respiration and excretion, as well as adaptations of growth and reproduction of $E$. hanseni to seasonal and regional differences in environmental conditions in the NBUS are discussed in relation to food availability and upwelling conditions. The influence of different MSs and SDSs on the respiratory activity is considered as well. Overall, seasonal differences in the physiological state of $E$. hansen $i$ in the NBUS off Namibia were small, whereas substantial regional differences were found.

\subsection{Seasonal comparison}

Seasonal differences between minimum and maximum upwelling conditions were apparent in SDS and moult activities but were neither found in respiration, excretion rates nor in O:N ratios. As shown for M. norvegica in the Kattegat and Clyde Sea (Saborowski et al., 2002), the lack of seasonal adjustments of metabolic rates may indicate favourable trophic conditions throughout the year. In the Kattegat and Clyde Sea, respiration rates of $M$. norvegica were mainly affected by temperature. Mediterranean $M$. norvegica in contrast, increased oxygen uptake strongly, but only during the short period of high primary production in an area with otherwise oligotrophic conditions, the Ligurian Sea (Saborowski et al., 2002). In comparison, the trophic conditions for $E$. hanseni in the NBUS appear favourable year-round and independent of the ups and downs of upwelling phases, as neither seasonal depression nor increase in metabolic rates were observed. This notion is further supported by the satellite images (Fig. 2) recorded during minimum (austral summer) and maximum (austral winter) upwelling, which show only minor variations in Chl $a$ values. Consequently, we did not find a close temporal coupling between upwelling conditions and primary productivity (cf. Martin et al., 2014). The constancy in Chl $a$ levels may be explained by strong mixing and turbulence in the upper water layers during intense, long-lasting upwelling events, inhibiting primary production (Bartholomae and van der Plas, 2007). Furthermore, monthly averages of Chl $a$ values varied between $1.5-3.5 \mathrm{mg} \mathrm{m}^{-3}$ similar to blooming conditions in most of the world's oceans, where Chl $a$ values typically range from less than 0.1 up to $1 \mathrm{mg} \mathrm{m}^{-3}$ (mean $0.19 \mathrm{mg} \mathrm{m}^{-3}$; Antoine et al., 1996). It is most likely, that in the NBUS nutrient input is high enough to sustain a sufficiently large (phyto-) plankton biomass throughout the year, thus providing constant and favourable feeding conditions for herbivorous and omnivorous zooplankton species, such as E. hanseni.

E. hanseni caught during austral summer 2011, i.e., the off-peak upwelling season, showed a higher percentage of animals in actively moulting and fewer animals in resting stages compared to austral winter conditions, i.e., the upwelling maximum. More specimens were found at the onset of ovarian development, with fewer females close to a spawning event. These findings may point to a seasonal adjustment of growth and reproduction, as shown for many other euphausiid species (Cuzin-Roudy and Buchholz, 1999; Meyer et al., 2010; Pinchuk and Hopcroft, 2007). During austral summer, animals may make use of higher water temperatures in the upper water layers (see Fig. 2), as growth in zooplankton, including euphausiids, is mainly triggered by temperature and food (e.g., Clarke and Peck, 1991; Hirst and Bunker,

Table 5

Distribution (\%) of moult phases of E. hanseni at different sampling stations (RPt, RPt-N and Kun-S) during austral winter 2010.

\begin{tabular}{|c|c|c|c|c|c|}
\hline & $\begin{array}{l}\text { Postmoult } \\
(\%)\end{array}$ & $\begin{array}{l}\text { Premoult } \\
(\%)\end{array}$ & $\begin{array}{l}\text { Active stages } \\
(\%)\end{array}$ & $\begin{array}{l}\text { Resting stages } \\
(\%)\end{array}$ & $\mathrm{N}$ \\
\hline & $(\mathrm{A}, \mathrm{B}, \mathrm{C})$ & $\left(D_{0}, D_{1}, D_{2}, D_{3}\right)$ & $\left(\mathrm{A}, \mathrm{B}, \mathrm{D}_{3}, \mathrm{E}\right)$ & $\left(C, D_{2}\right)$ & \\
\hline Rpt & 27 & 73 & 0 & 51 & 49 \\
\hline Rpt-N & 59 & 34 & 14 & 55 & 69 \\
\hline Kun-S & 45 & 52 & 27 & 43 & 44 \\
\hline
\end{tabular}

Table 6

Distribution (\%) of sexual maturity stages of E. hanseni at different sampling stations (RPt, RPt-N and Kun-S) during austral winter 2010.

\begin{tabular}{|c|c|c|c|c|c|}
\hline & $\begin{array}{l}\text { SDS } 1-2 \\
(\%)\end{array}$ & $\begin{array}{l}\text { SDS 3-5 } \\
(\%)\end{array}$ & $\begin{array}{l}\text { SDS } 3 \\
(\%)\end{array}$ & $\begin{array}{l}\text { SDS 4-5 } \\
(\%)\end{array}$ & $\mathrm{N}$ \\
\hline & $\begin{array}{l}\text { (Onset of ovarian } \\
\text { development) }\end{array}$ & (Vitellogenic) & (Resting stage) & (Ready to spawn) & \\
\hline Rpt & 0 & 100 & 40 & 60 & 40 \\
\hline Rpt-N & 79 & 21 & 21 & 0 & 33 \\
\hline Kun-S & 4 & 96 & 12 & 84 & 25 \\
\hline
\end{tabular}

2003; Huntley and Boyd, 1984). Nevertheless, many vitellogenic females and the occurrence of more than $70 \%$ females bearing spermatophores during both seasons indicate continuous breeding in E. hanseni throughout the year, as suggested by Barange and Stuart (1991). High somatic and moult productivity rates during the off-peak season were also found in other important krill species, such as Euphausia mucronata, in the Humboldt Current upwelling system (Riquelme-Bugueno et al., 2013). Despite of strong seasonal differences in upwelling intensity, E. mucronata shows continuous year-round production and reproduction, likewise not restricted by season. Generally, as omnivorous species, E. hanseni as well as E. mucronata may receive sufficient food to perpetuate growth and reproduction in these highly productive upwelling ecosystems. From the euphausiid perspective it appears that the NBUS supports life in a 'Sea of Plenty', with a high moult and reproductive activity year-round and no need for seasonal reversal of metabolic activities.

\subsection{Regional comparison}

Krill swarms caught at station RPt and Kun-S showed similar respiration rates (12.1-13.0 $\mu \mathrm{mol} \mathrm{O}_{2} \mathrm{~h}^{-1} \mathrm{~g}_{\mathrm{ww}}{ }^{-1}$ ) and either high moult activities and/or a high SDS of females. At RPt no animals were in an active moult stage, however, this may be explained by the high SDSs of the females at this station. It is likely, that these animals were close to a spawning event which was denoted by many females showing an ovary with an orange hue (pers. obs.) indicating imminent spawning. In contrast, the animals at station RPt-N had significantly lower respiration rates, lower O:N ratios and showed 'normal' moult activity and low SDS. Studies on E. superba indicated that food availability affects moult frequency (Buchholz and Buchholz, 1989) and that higher temperatures decrease the intermoult period (Buchholz, 2003). Since

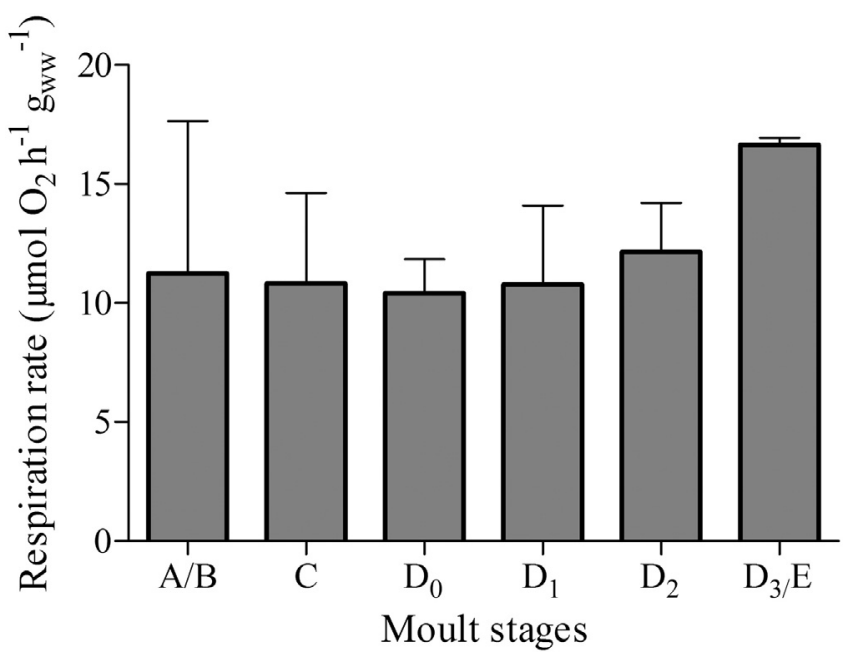

Fig. 6. Moult stages of Euphausia hanseni and corresponding respiration rates $\left(\mu \mathrm{mol} \mathrm{O}_{2} \mathrm{~h}^{-1} \mathrm{~g}_{\mathrm{ww}}{ }^{-1}\right)$ at $10^{\circ} \mathrm{C}$. Bars represent mean values $(\mathrm{N}=2-18)$ with standard deviations. 


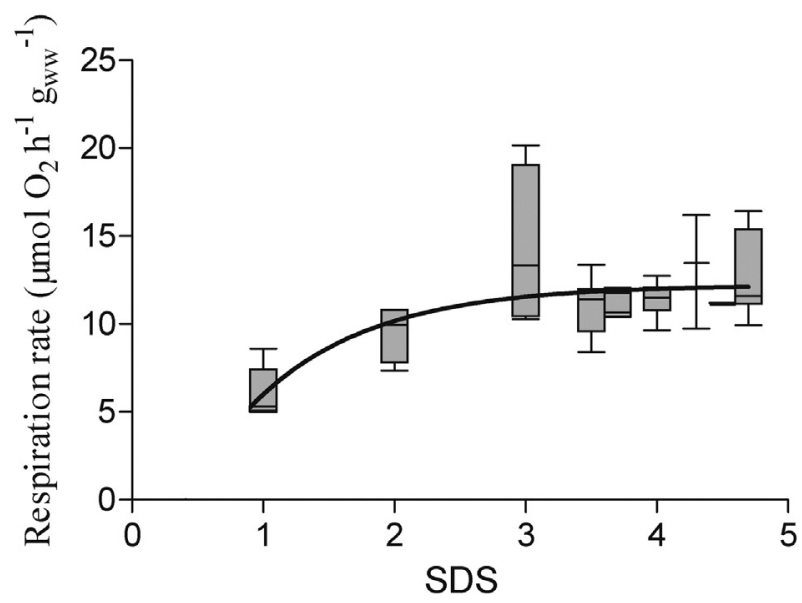

Fig. 7. Box and whisker plots of the sexual developmental stages (SDS) of Euphausia hanseni females $(\mathrm{N}=4-9)$ and corresponding respiration rates $\left(\mu \mathrm{mol} \mathrm{O} \mathrm{O}^{-1} \mathrm{~g}_{\mathrm{ww}}{ }^{-1}\right.$ ) at $10{ }^{\circ} \mathrm{C}$ fitted with a non-linear regression [black line: $\mathrm{y}=-6.761+$ $18.981 *(1-\exp (-1.114 * \mathrm{x}))]$.

favourable trophic conditions promote synchronized moult activities (Buchholz et al., 1996) and reproduction (Tarling and Cuzin-Roudy, 2003), high moult or reproductive activity may be considered indicative of favourable food conditions prior to sampling. Accordingly, it is assumed that animals at station RPt-N were exposed to unfavourable environmental conditions, e.g., trapped in nutrient-poor eddies with low productivity (Gruber et al., 2011), leading to reduced oxygen consumption and lower O:N ratios. Frequent oceanic features of upwelling systems, such as filaments and eddies, may lead to pronounced mesoscale differences in hydrographic and trophic conditions affecting the physiological state of zooplankton. The lack of females being in SDS 4-5 at that station further supports the assumption of poor trophic conditions prior to sampling. Reduced metabolism is a common way of zooplankton to save energy under starvation and could reflect depression of several physiological processes at the same time (see below). Nevertheless, we cannot entirely reject the possibility that the animals just passed a spawning event, resulting in low SDS. Huenerlage and Buchholz (2013) have shown that under experimental food deprivation E. hanseni immediately down-regulates metabolic parameters such as respiration and excretion rates. This fits our findings only partly, as respiration rates at station RPt were reduced but excretion rates remained unchanged. We suggest that E. hanseni, as opportunistic omnivores, unlike in starvation experiments, seldom or maybe never, experience complete food absence over a longer period in the NBUS, leading to comparable excretion rates at the different stations.

\subsection{Influence of MS and SDS on oxygen uptake}

In E. hanseni no significant differences in respiration rates were detected between the postmoult and premoult phases or between active and non-active moult phases. This held true even after all females were excluded from the analyses, to avoid biasing the results by different SDSs. The high $R R_{2}$ found during the active moult phases $D_{3}$ and Ecdysis may point to accelerated metabolic activities during the actual moult in E. hanseni. However, most of the animals investigated during this study were in MS C. Under unfavourable conditions (e.g., starvation) or at the onset of sexual maturation, the time span of this moult stage can be prolonged (Buchholz, 1982). Accordingly, stage $C$ is considered as a "resting stage" in the moulting process, analogous to SDS $1+3$ in female reproductive development, and can be viewed as an immediate starting point for moulting when conditions become suitable. Buchholz (2003) reviewed that the intermoult period (IMP) of E. superba decreases with increasing water temperatures, and that this species can quickly adjust its IMP and size increment at moult (INC) to the prevailing feeding conditions. Moulting is influenced by several factors, including water temperature and food supply which in turn can relate to oxygen uptake and demand. Accordingly, other factors such as the nutritional state of the animals may have interfered with the detection of different energy requirements between moult phases.

However, our results show that the SDS of E. hanseni females positively influenced respiration rates (Fig. 7), and that moult stage in both sexes did not affect the oxygen uptake (Fig. 6), even when the actual ecdysis seemed to require higher energy expenditure. Thus, the observed differences in the metabolic activity between regions may be mainly due to differential reproductive effort. Most of the females at RPt-N were in a SDS of 1 or 2, stages where ovaries are still developing and differentiating. Ovaries of females from the other stations were mostly fully developed (SDS 3 and higher) and some even displayed an orange hue, an indicator of egg maturation. High frequencies of SDS $3+$ may be seen as an indication for suitable trophic conditions. The significantly lower oxygen uptake of both sexes at RPt-N compared to the other stations may suggest a reduction of metabolic rates corresponding to low reproductive effort within the whole swarm.

Respiration rates were highly variable in SDS 3 (vitellogenesis). The low oxygen uptake in some SDS 3 females could indicate a "waiting for favourable conditions" strategy, whereas the high rates observed in other SDS 3 females may point to a "kick-off" in the spawning cycle. Both do not reject the scenario of a "waiting" stage in the reproductive cycle, where krill females with nearly fully developed oocytes "wait for favourable conditions", followed by the initiation of maturation and spawning if conditions allow. The strategy of waiting for favourable conditions is most likely an adaptation to periodic short time-scale upwelling events, which could boost reproductive success in E. hanseni. Species such as $M$. norvegica go through multiple egg production cycles during the reproductive season, followed by a longer period of sexual rest (Cuzin-Roudy and Buchholz, 1999). Under experimental conditions, $M$. norvegica females showed oosorption after 2 days of starvation (Cuzin-Roudy and Buchholz, 1999), allowing to re-start egg preparation when trophic conditions improved. However, reproductive scheduling in other krill species coincides with periods of optimal feeding conditions (Cuzin-Roudy and Buchholz, 1999). Thus, a "waiting" stage, where females bear fully developed oocytes yet wait to spawn, may allow them to respond quickly to improving trophic conditions and could well evolve in poly-pulsed systems with perennial upwelling events. Ideally, vitellogenesis should only occur when trophic conditions are optimal in order to promote strong non-feeding stages of larvae, due to the optimal development and condition of eggs (Tarling and Cuzin-Roudy, 2003). The quality and quantity of food influence growth rates in feeding stages of krill larvae and accordingly, the onset of upwelling would be a critical period for this developmental stage (Siegel, 2000). Our results agree with observations in other krill species. In the southern Benguela Current, Euphausia lucens spawned before the onset of upwelling and the spring phytoplankton bloom associated with it (Pillar and Stuart, 1988), thereby ensuring that the larvae hatched during a period of high food supply. Dorman et al. (2005) showed that short time-scale fluctuations in Chl $a$ concentrations due to changes in the upwelling state positively affect the amount of eggs spawned by Euphausia pacifica. Spawning intensities for E. pacifica were highest during upwelling events due to high food supply (Brinton, 1976; Smiles and Pearcy, 1971). The subsequent zooplankton bloom may be of further importance for omnivorous species like E. lucens (Siegel, 2000) and E. hanseni. Upwelling events often induce phytoplankton blooms in the NBUS and also correlate with high SDSs in E. hanseni, as similarly observed in E. lucens and E. pacifica. Prolonged upwelling-favourable winds decreased the reproductive effort and abundance of E. pacifica both on short- and inter-annual time scales (Dorman et al., 2005). Accordingly, there may be an optimal upwelling intensity which supports reproduction in euphausiids by favouring primary and secondary production without advecting plankton too far 
off-shore (Dorman et al., 2005), especially in species such as E. hanseni, which releases eggs in the surface layers which are then transported offshore (Barange and Pillar, 1992). However, further analyses are needed to detail the ovarian development cycle in E. hanseni females as it relates to upwelling and food availability and to clarify whether this species spawns continuously or in multiple discrete periods (Siegel, 2000).

\subsection{Species comparison}

Euphausiids are distributed worldwide, ranging from tropical waters to high latitude polar regions and are key components of the pelagic food web. Euphausiids exert top-down control on a large variety of pelagic invertebrates and phytoplankton and at the same time are a food basis for a wide range of fish, birds and also mammals. They inhabit marine ecosystems with marked differences in (seasonal and spatial) trophic conditions.

The well-studied species $M$. norvegica is wide spread, ranging from boreal to sub-tropical North Atlantic waters and adjacent seas. E. superba, with a lifespan of up to 6 years, is restricted to the Antarctic ring ocean and constitutes the largest stock of crustacean biomass in the world's ocean. E. hanseni inhabits coastal Atlantic waters at the margin of the African continent at both sides of the equator (Mauchline and Fisher, 1969). The seasonal changes in food availability therefore differ greatly between $M$. norvegica, E. superba and $E$. hanseni and this is reflected in their metabolic and physiological adaptations. M. norvegica encounters different trophic regimes both spatially and seasonally (e.g., Mediterranean Sea). E. superba mainly experiences drastic seasonal differences in food availability (favourable in austral summer, poor in austral winter). Trophic conditions for E. hanseni are comparably favourable and consistently good throughout the year, largely controlled by upwelling events. Thus, this species experiences both spatial and temporal mesoscale fluctuations, like e.g., E. mucronata in the Humboldt Current System. All three species are omnivorous, reflecting their capability to adapt to the highly variable trophic conditions in their environments (cf. Buchholz and Saborowski, 2000). The seasonal adjustments of metabolic rates in relation to food availability in these krill species from different climatic zones are discussed below.

In M. norvegica, metabolic adaptations, as measured through respiration and excretion rates, were recorded in response to the variable trophic conditions prevailing in the Mediterranean Sea, where a short productive season is followed by a long period of oligotrophic conditions. Enhanced somatic growth, reproductive activity and development correlated with favourable trophic conditions during the short period(s) of increased food availability (Saborowski et al., 2002). In contrast, animals from areas with comparably constant food supply, such as the Kattegat and the Clyde Sea, displayed no seasonal adjustment of respiration and excretion rates (Saborowski et al., 2002). In the case of the Kattegat and Clyde Sea populations, predominantly temperature affected metabolic rates positively. In general, $M$. norvegica preferentially displays long-term adaptations to prevailing environmental conditions rather than short-term adjustments of metabolic rates. In E. superba, respiration rates may be reduced by up to 60\% during austral autumn and winter, the periods of limited food supply (Atkinson et al., 2002; Meyer et al., 2010; Torres et al., 1994). Reduced metabolic activity accompanied by reduced feeding and growth are considered adaptations to austral winter conditions in Antarctic waters. Reduced metabolic activity and the accumulation of large lipid reserves allows E. superba to survive periods without an autotrophic food supply in the water column (Meyer et al., 2010). Furthermore, low omnivorous feeding activities account for a sufficient energy input during winter (Meyer et al., 2010). Thus, E. superba displays pronounced seasonal adaptations of metabolic rates as a function of food availability during austral winter. According to our results metabolic activity, growth, and reproductive effort in E. hanseni are adapted to the spatial mesoscale variability in trophic conditions. Upwelling events influence growth and reproduction which in turn affect metabolic rates. This species directly invests energy into reproduction and growth, without storing large lipid reserves (Huenerlage and Buchholz, 2013). E. hanseni in the NBUS can be considered as living from hand-to-mouth but well adapted to life in a 'Sea of Plenty'.

All three species are well adapted to the highly variable trophic conditions in their particular environment/ecosystem and their physiological performance directly reflects the prevailing conditions. Different time scales of changes in environmental conditions between these species may have led to different acclimatization patterns in E. hanseni, E. superba and M. norvegica: E. hanseni reduces metabolic activity under food limitation and immediately enhances physiological performance when food conditions improve, though only in response to short-term and meso-scale events. E. superba shows a drastic seasonal reduction of metabolic rates correlated with low food availability, whereas $M$. norvegica only shows enhanced metabolism during the spring phytoplankton bloom in areas with seasonal food shortages. Overall, krill species are able to quickly respond to improving environmental conditions and efficiently convert energy surplus into growth and reproduction (Buchholz and Saborowski, 2000). Accordingly, euphausiids may serve as useful indicators of short-term or small scale changes in environmental conditions (e.g., food availability and temperature) as well as long-term and large-scale differences (e.g., climate related changes).

\section{Acknowledgements}

We wish to thank the Captain and crew of the RRS Discovery and RV Maria S. Merian for their excellent assistance with collection of samples on board and our GENUS - colleagues from Angola, Namibia, South Africa, and Germany for the generous help. Special thanks to N. Lahajnar (University of Hamburg, Germany) for providing Ferrybox data. Visualizations used in this paper (Fig. 2) were produced with the Giovanni online data system. The data were acquired as part of the activities of NASA's Science Mission Directorate, and are archived and distributed by the Goddard Earth Sciences (GES) Data and Information Services Center (DISC). This study formed part of the GENUS project, funded by the Bundesministerium für Bildung und Forschung (BMBF, 03F0497F, Germany) and the Alfred-Wegener-Institute, Helmholtz Centre for Polar and Marine Research (PACES, WP2T2). GENUS aims to clarify relationships between climate change, biogeochemical cycles, and ecosystem structure in the large marine ecosystem of the northern Benguela off the Namibian Coast.

\section{References}

Antoine, D., Andre, J.M., Morel, A., 1996. Oceanic primary production 2. Estimation at global scale from satellite (coastal zone color scanner) chlorophyll. Glob. Biogeochem. Cycles 10, 57-69.

Atkinson, A., Meyer, B., Stübing, D., Hagen, W., Bathmann, U.V., 2002. Feeding and energy budgets of Antarctic krill Euphausia superba at the onset of winter. II. Juveniles and adults. Limnol. Oceanogr. 47, 953-966.

Barange, M., 1990. Vertical migration and habitat partitioning of six euphausiid species in the northern Benguela upwelling system. J. Plankton Res. 12 (6), 1223-1237.

Barange, M., Pillar, S.C., 1992. Cross-shelf circulation, zonation and maintenance mechanisms of Nyctiphanes capensis and Euphauisa hanseni (Euphausiacea) in the northern Benguela upwelling system. Cont. Shelf Res. 12, 1027-1042.

Barange, M., Stuart, V., 1991. Distribution patterns, abundance and population dynamics of the euphausiids Nyctiphanes capensis and Euphausia hanseni in the northern Benguela upwelling system. Mar. Biol. 109, 93-101.

Bartholomae, C.H., van der Plas, A.K., 2007. Towards the development of environmental indices for the Namibian shelf, with particular references to fisheries management. Afr. J. Mar. Sci. 29, 25-35.

Brinton, E., 1976. Population biology of Euphausia pacifica of southern California. Fish. Bull. U.S. 74, 733-762.

Buchholz, F., 1982. Drach's moult staging system adapted for euphausiids. Mar. Biol. 66, 301-305.

Buchholz, F., 1991. Moult cycle and growth of Antarctic krill Euphausia superba in the laboratory. Mar. Ecol. Prog. Ser. 69, 217-229. 
Buchholz, F., 2003. Experiments on the physiology of Southern and Northern krill, Euphausia superba and Meganyctiphanes norvegica, with emphasis on moult and growth - a review. Mar. Freshw. Behav. Physiol. 36, 229-247.

Buchholz, C., Buchholz, F., 1989. Ultrastructure of the integument of a pelagic crustacean: moult cycle related studies on the Antarctic krill, Euphausia superba. Mar. Biol. 101, 355-365.

Buchholz, F., Buchholz, C., 2010. Growth and moulting in Northern Krill (Meganyctiphanes norvegica SARS). In: Tarling, G.A. (Ed.), Adv Mar Biol. Biology of Northern Krill 57, pp. 174-194.

Buchholz, F., Saborowski, R., 2000. Metabolic and enzymatic adaptations in northern krill, Meganyctiphanes norvegica, and Antarctic krill, Euphausia superba. Can. J. Fish. Aquat. Sci. 57, 115-129.

Buchholz, F., Watkins, J.L., Priddle, J., Morris, D.J., Ricketts, C., 1996. Moult in relation to some aspects of reproduction and growth in swarms of Antarctic krill, Euphausia superba. Mar. Biol. 127, 201-208.

Buchholz, F., et al., 2010. Report of Cruise D356 RRS Discovery.

Clarke, A., Peck, L.S., 1991. The physiology of polar marine zooplankton. Polar Res. 10, 355-370.

Conover, R.J., Corner, E.D.S., 1968. Respiration and nitrogen excretion by some marine zooplankton in relation to their life cycles. J. Mar. Biol. Assoc. UK 48, 49-75.

Cuzin-Roudy, J., 1993. Reproductive strategies of the mediterranean krill, Meganyctiphanes norvegica and the Antarctic krill, Euphausia superba (Crustacea: Euphausiacea). Invertebr. Reprod. Dev. 23, 105-114.

Cuzin-Roudy, J., Buchholz, F., 1999. Ovarian development and spawning in relation to the moult cycle in Northern krill, Meganyctiphanes norvegica (Crustacea: Euphausiacea), along a climatic gradient. Mar. Biol. 133, 267-281.

Dorman, J.G., Bollens, S.M., Slaughter, A.M., 2005. Population biology of euphausiids off northern California and effects of short time-scale wind events on Euphausia pacifica. Mar. Ecol. Prog. Ser. 288, 183-198.

Gruber, N., Lachkar, Z., Frenzel, H., Marchesiello, P., Münnich, M., McWilliams, J., Nagai, T., Plattner, G.-K., 2011. Eddy-induced reduction of biological production in eastern boundary upwelling systems. Nat. Geosci. 4, 787-792.

Hirst, A.G., Bunker, A.J., 2003. Growth of marine planktonic copepods: global rates and patterns in relation to chlorophyll $a$, temperature and body weight. Limnol. Oceanogr. 48, 1988-2010.

Huenerlage, K., Buchholz, F., 2013. Krill of the northern Benguela Current and the AngolaBenguela frontal zone compared: physiological performance and short-term starvation in Euphausia hanseni. J. Plankton Res. 35 (2), 337-351.

Huntley, M., Boyd, C., 1984. Food-limited growth of marine zooplankton. Am. Nat. 124, 455-478.

Hutchings, L., Van Der Lingen, C.D., Shannon, L.J., Crawford, R.J.M., Verheye, H.M.S., Bartholomae, C.H., Van Der Plas, A.K., Louw, D., Kreiner, A., Ostrowski, M., Fidel, Q. Barlow, R.G., Lamont, T., Coetzee, J., Shillington, F., Veitch, J., Currie, J.C., Monteiro, P.M.S., 2009. The Benguela Current: an ecosystem of four components. Prog. Oceanogr. 83, 15-32.

Ikeda, T., Mitchell, A.W., 1982. Oxygen uptake, ammonia excretion and phosphate excretion by krill and other Antarctic zooplankton in relation to their body size and chemical composition. Mar. Biol. 73, 283-298.

Kim, H.S., Yamaguchi, A., Ikeda, T., 2010. Population dynamics of the euphausiids Euphausia pacifica and Thysanoessa inspinata in the Oyashio region during the 2007 spring phytoplankton bloom. Deep-Sea Res. II Top. Stud. Oceanogr. 57, 1727-1732.

Lahajnar, N., et al., 2011. Maria S. Merian-Berichte 17-3, Cruise 17, Leg 3. DFG Senatskommission für Ozeanographie, Walvis Bay-Dakar (Jan.-Mar. 2011).

Martin, B., Eggert, A., Mohrholz, V., Schmidt, M., Diekmann, R., Koppelmann, R., 2014. Spatio-temporal variability of mesozooplankton biomass and environmental control in the northern Benguela Upwelling System: field investigations and model simulation. Mar. Ecol. 1-22. http://dx.doi.org/10.1111/maec.12173.
Mauchline, J., Fisher, L.R., 1969. The biology of euphausiids. In: Frederick, S.R., Maurice, Y. (Eds.), Adv Mar Biol 7. Academic Press.

Mayzaud, P., Conover, 1988. O:N atomic ratio as a tool to describe zooplankton metabolism. Mar. Ecol. Prog. Ser. 45 (3), 289-302.

Meyer, B., Fuentes, V., Guerra, C., Schmidt, K., Atkinson, A., Spahic, S., Cisewski, B., Freier U., Olariaga, A., Bathmann, U., 2009. Physiology, growth and development of larval krill Euphausia superba in autumn and winter in the Lazarev Sea, Antarctica. Mar. Ecol. Prog. Ser. 398, 1-18.

Meyer, B., Auerswald, L., Siegel, V., Spahic, S., Pape, C., Fach, B., Teschke, M., Lopata, A.L. Fuentes, V., 2010. Seasonal variation in body composition, metabolic activity, feeding, and growth of adult krill Euphausia superba in the Lazarev Sea. Mar. Ecol. Prog. Ser. $398,1-18$.

Mohrholz, V., Schmidt, M., Lutjeharms, J.R.E., 2001. The hydrography and dynamics of the Angola-Benguela frontal zone and environment in April 1999. Afr. J. Mar. Sci. 97 199-208.

Monteiro, A.K., van der Plas, J.-L., Mélice, P.F., 2008. Interannual hypoxia variability in a coastal upwelling system: ocean-shelf exchange, climate and ecosystem-state implications. Deep-Sea Res. I 55, 435-450.

Pillar, S.C., Stuart, V., 1988. Population structure, reproductive biology and maintenance of Euphausia lucens in the southern Benguela Current. J. Plankton Res. 10, 1083-1089.

Pinchuk, A.I., Hopcroft, R.R., 2007. Seasonal variations in the growth of euphausiids (Thysanoessa inermis, T. spinifera, and Euphausia pacifica) from the northern Gulf of Alaska. Mar. Biol. 151, 247-269.

Riquelme-Bugueno, R., Escribano, R., Gomez-Gutierrez, J., 2013. Somatic and moult production in Euphausia mucronata off central-southern Chile: the influence of coastal upwelling variability. Mar. Ecol. Prog. Ser. 476, 39-57.

Saborowski, R., Bröhl, S., Tarling, G., Buchholz, F., 2002. Metabolic properties of Northern krill, Meganyctiphanes norvegica, from different climatic zones. I. Respiration and excretion. Mar. Biol. 140, 547-556.

Schlitzer, R., 2015. Ocean Data View. odv.awi.de.

Shannon, L.V., 1985. The Benguela ecosystem: 1. Evolution of the Benguela, physica features and processes. Oceanogr. Mar. Biol. Annu. Rev. 23, 105-182.

Shannon, L.V., Nelson, G., 1996. The Benguela: large scale features and processes and system variability. In: Wefer, G., Berger, W.H., Siedler, G., Webb, D.J. (Eds.), The South Atlantic: Present and Past Circulation. Springer-Verlag, Berlin, pp. 163-210.

Siegel, V., 2000. Krill (Euphausiacea) life history and aspects of population dynamics. Can. J. Fish. Aquat. Sci. 57, 130-150.

Smiles, M.C., Pearcy, W.G., 1971. Size structure and growth rate of Euphausia pacifica of the Oregon coast. Fish. Bull. U.S. 69, 79-86.

Solorzano, L., 1969. Determination of ammonia in natural waters by the phenol hypochlorite method. Limnol. Oceanogr. 14, 799-801.

Tarling, G., Cuzin-Roudy, J., 2003. Synchronization in the moulting and spawning activity of northern krill (Meganyctiphanes norvegica) and its effect on recruitment. Limnol. Oceanogr. 48, 2020-2033.

Torres, J.J., Aarset, A.V., Donnelly, J., Hopkins, T.L., Lancraft, T.M., Ainley, D.G., 1994. Metabolism of Antarctic micronektonic Crustacea as a function of depth occurrence and season. Mar. Ecol. Prog. Ser. 113, 207-219.

Werner, T., Buchholz, F., 2013. Diel vertical migration behaviour in Euphausiids of the northern Benguela current: seasonal adaptations to food availability and strong gradients of temperature and oxygen. J. Plankton Res. 35 (4), 792-812.

Werner, T., Huenerlage, K., Verheye, H.M.S., Buchholz, F., 2012. Thermal constraints on the respiration and excretion rates of krill, Euphausia hanseni and Nematoscelis megalops, in the northern Benguela upwelling system off Namibia. Afr. J. Mar. Sci. 34 (3), 391-399.

Wiebe, P.H., Morton, A.W., Bradley, A.M., Backus, R.H., Craddock, J.E., Barber, V., Cowles, T.J., Flierl, G.R., 1985. New development in the MOCNESS, an apparatus for sampling zooplankton and micronekton. Mar. Biol. 87, 313-323. 